УДК 343.93

DOI https://doi.org/10.32837/apdp.v0i85.1820

А. В. Боровик

\title{
ЩОДО ЄВРОПЕЙСЬКИХ СТАНДАРТІВ КРИМІНАЛЬНОЇ ВІДПОВІДАЛЬНОСТІ ЗА КОРУПЦІЙНІ КРИМІНАЛЬНІ ПРАВОПОРУШЕННЯ ТА ЇХ ЗАПОБІГАННЯ
}

Постановка проблеми. Зважаючи на положення Преамбули, п. 5 ст. 85, ч. 2 ст. 102, п. 1-1 ст. 116 Конституції України (щодо «європейської ідентичності українського народу і незворотності європейського курсу України», а також «стратегічного курсу держави на набуття повноправного членства України в Європейському Союзі»), історичну, географічну та політичну наближеність нашої держави до країн Європейського Союзу (далі - ЄC), актуальним завданням є здійснення наукового дослідження європейських стандартів кримінальної відповідальності за корупційні кримінальні правопорушення (далі - ККП) та їх запобігання.

На думку Т. Мурхед, право ЄС за своєю сутністю є однією з галузей міжнародного права, оскільки примат зобов'язань ЄС у державах-членах ЄС грунтується на принципі верховенства міжнародно-правових зобов’язань [1, с. 138-141]. Щодо кримінального права ЄС, то воно має свої особливості (зокрема, існує в рамках так званої «третьої опори співробітництва» та репрезентоване численними конвенціями і договорами, які містять гіпотезу, тоді як диспозиція та санкція передбачені в національному кримінальному законі) [2, с. 496], тим більше в частині кримінальної відповідальності за ККП. Аналогічні позиції будуть прийнятними й щодо запобігання ККП. Загалом опанування європейським досвідом щодо протидії та запобігання корупційним діянням буде корисним для України в теоретичному та прикладному плані.

Аналіз останніх досліджень і публікацій. Розробку проблемних питань щодо європейських стандартів кримінальної відповідальності за ККП та їх запобігання здійснювали у своїх працях різні науковці, зокрема О.І. Бідна, Р. Брату (R. Bratu), К.В. Воронежський, Д.О. Гарбазей, С.В. Дрьомов, Т.Л. Козлов, В. Міцілегас (V. Mitsilegas), Ю.С. Нагачевська, І.С. Нуруллаєв, М.І. Пашковський, А.В. Савченко, М.І. Хавронюк, Ю.Б. Хім'як та інші. Водночас у працях згаданих науковців повністю не були враховані тенденції щодо змін антикорупційного законодавства на європейському та національних рівнях, не взяті до уваги особливості тлумачення тих чи інших європейських конвенцій, не досліджені тонкощі механізмів протидії та запобігання корупційним діянням тощо.

Метою статті є встановлення особливостей європейських стандартів щодо кримінальної відповідальності за ККП та їх запобігання, а також визначення напрямів і формату удосконалення національного антикорупційного законодавства та кримінально-правової політики.

Виклад основного матеріалу дослідження. 3 огляду на європейські стандарти в галузі кримінального права, О.В. Гончарук констатує про такі важливі моменти: 1) підвалини кримінально-правового співробітництва та уніфікації законодавства 
держав-членів ЄС були закладені Маастрихтською угодою 1992 року, відповідно до якої держави: а) здійснюють активне співробітництво у кримінально-правовій сфері; б) надають правову допомогу у кримінальних справах; в) вирішують питання екстрадиції та співробітництва оперативно-розшукових служб у процесі виконання своїх обов'язків; 2) питання уніфікації деяких кримінально-правових норм Маастрихтської угоди згодом відбилися і в Амстердамських домовленостях 1997 року; 3) у 2000-2005 роках співробітництво держав у сфері кримінально-правового регулювання було реалізовано в питаннях вироблення спільної зовнішньої політики та політики безпеки [3, с. 67-69].

У Лісабонському договорі (набув чинності 01.12.2009) реформа співпраці правоохоронних органів держав-членів у кримінально-правовій сфері була однією 3 найглибших і найпомітніших, при цьому зазначений договір скасував систему «трьох опор», а колишня ст. 31 Маастрихтського договору була замінена на ст. 83 Договору про функціонування ЄС, де були врегульовані й питання боротьби з корупцією, а нормотворча процедура в кримінально-правовій сфері була передбачена ст. 294 Договору про функціонування ЄС [4, с. 55-57].

Науковці зазначають про неоднорідність кримінального права ЄC, виділяючи в ньому такі складники: 1) адміністративно-кримінальне право $6 C ; 2$ ) норми права ЄC, які стосуються кримінального права та процесу, що здебільшого вимагають від національних кримінально-правових систем здійснювати заходи певним чином; 3) кримінально-процесуальне право ЄС; 4) проєкт норм єдиного європейського кримінального права (Corpus Juris) [5, с. 47].

На думку Дж. Вогель, нині доречно говорити про формування особливої (відокремленої) кримінально-правової системи ЄС та концепції інтеграційної системи кримінальної юстиції ЄС, при цьмуу в останній можна виділити нормативний, інституційний та емпіричний елементи [6, с. 134-142]. О.М. Трикоз наголошує, що європейська інтеграція не означає, що йдеться про радикальне втручання в сферу національноїкримінальноїюстиціїабоскасування,централізаціючитотальнууніфікацію кримінально-правових систем держав-членів ЄС. Вони продовжують інтегруватися завдяки політиці кооперації, координації та гармонізації кримінально-правової сфери (при цьому уніфікація кримінального права означає правову інтеграцію специфічних сфер, наприклад сфери захисту фінансових інтересів СС або секторальну гармонізацію матеріального і процесуального кримінального права) [7, с. 90].

Так, у низці нормативно-правових актів ЄС наголошується, що протидія корупційним виявам є запорукою забезпечення захисту фінансових інтересів Європейських співтовариств [8, с. 80-84]. Зокрема, йдеться про:

1) Протокол від 27.09.1996, який доповнює Конвенцію про захист фінансових інтересів Свропейських співтовариств від 26.07.1995, в якому зазначено про необхідність: а) боротьби з корупційними діяннями, що вчиняються за участю відповідних посадових осіб; б) вжиття необхідних заходів для забезпечення визнання кримінальним правопорушенням пасивну (ст. 2) та активну (ст. 3) корупцію; в) встановлення дієвих, пропорційних і стримувальних кримінальних санкцій, в тому числі у вигляді позбавлення волі, які можуть бути підставою для екстрадиції (ст. 5); 
2) Другий Протокол до зазначеної вище Конвенщї̈ від 19.06.1997, де передбачено: а) адаптацію національних законодавств щодо притягнення юридичних осіб до відповідальності за шахрайство або активну корупцію та відмивання грошей, які завдають або можуть завдати шкоди фінансовим інтересам Свропейських співтовариств (ст. 3); б) встановлення санкцій проти юридичних осіб (позбавлення права на державні пільги або допомогу; тимчасове або постійне позбавлення права вести комерційну діяльність; встановлення судового нагляду; судове рішення про ліквідацію) та конфіскацію їх доходів (ст.ст. 4 та 5); в) забезпечення співпраці між державами-членами та Комісією Свропейських співтовариств;

3) Міжінституційну угоду від 25.05.1999 між Європейським Парламентом, Радою СС і Комісією Свропейських співтовариств про внутрішні розслідування Європейського бюро боротьби з шахрайством (OLAF), в якій зазначалося про схвалення імплементаційних інструментів щодо забезпечення належного проведення вказаним бюро розслідувань, що мають на меті боротьбу з шахрайством, корупцією та іншою незаконною діяльністю, яка шкодить фінансовим інтересам Європейських співтовариств;

4) Директиву (СС) 2017/1371 Свропейського парламенту та Ради від 05.07.2017 про боротьбу з шахрайством, спрямованим проти фінансових інтересів Союзу, кримінально-правовими засобали, де до кримінальних правопорушень, які завдають шкоди фінансовим інтересам Союзу, віднесено шахрайство (ст. 3), а також відмивання грошей, пасивну та активну корупцію, неправомірне використання коштів (ст. 4). 3 цього можна зробити такі висновки: корупційне діяння (пасивне або активне) може вчинятися як прямо, так і через посередника; предмет корупційного діяння необмежений - будь-яка вигода; корупційне діяння (пасивне - вимагання або одержання будь-які вигоди для себе чи для третьої сторони або прийняття обіцянки такої вигоди; активне - обіцянка, пропозиція чи надання) вчиняється в обмін на свої дії або утримання від діїзгідно зі своїми посадовими обов' язками, або при здійсненні покладених функцій; внаслідок корупційного діяння завжди завдається шкода або існує вірогідність її завдання фінансовим інтересам ЄС.

Кримінально-караними мають бути й підбурювання, сприяння, пособництво та замах на вчинення будь-якого з перерахованих вище кримінальних правопорушень. Максимальним покаранням для фізичної особи має стати позбавлення волі щонайменше на чотири роки в разі завдання істотної шкоди або одержання істотної вигоди. Санкціями щодо юридичних осіб повинні стати кримінальні чи некримінальні штрафи та інші санкції, зокрема позбавлення права на державні пільги або допомогу; тимчасове або постійне позбавлення права брати участь у процедурах публічних закупівель; тимчасове або постійне позбавлення права вести комерційну діяльність; встановлення судового нагляду; судове рішення про ліквідацію; тимчасове або постійне закриття закладів, які використовувалися для вчинення кримінального правопорушення. В плані запобігання кримінальним правопорушенням, в тому числі корупційним, мають бути вирішені питання арешту та конфіскації кримінальних засобів вчинення та доходів, юрисдикції, повернення коштів, співпраці між державами-членами і комісією (OLAF) та іншими інституціями, органами, офісами та агентствами $\mathrm{CC}$ тощо. 
Важливі положення щодо відповідальності за ККП містяться й у Модельному $\boldsymbol{K} \boldsymbol{K} \boldsymbol{C C}$ (оригінальна назва - “Corpus Juris 2000”), де в ст. 5 «Корупція» визначено термін «службова особа» та запропоновано криміналізувати пасивну й активну корупцію, якщо протиправні діяння шкодять фінансовим інтересам ЄС або створюють загрозу їх завдання. Кримінальна відповідальність має наставати й за змову на вчинення цього ККП. Покаранням за таке діяння має стати: для фізичної особи - тюремне ув'язнення на строк до 5 років (за обтяжуючих обставин - 7) та/або штраф; для організації - штраф до 10 млн євро. Додатковим покаранням може бути опублікування вироку; виключення з категорії тих, кому можуть надаватися субсидії по праву ЄС або хто може укладати контракти з публічною владою, що використовує фонди Співтовариства; заборона працювати службовою особою ЄС та національною службовою особою на строк до 5 років [9].

Специфікою міжнародних угод, прийнятих в рамках ЄС у сфері боротьби 3 корупцією, як стверджує Д.О. Гарбазей, є: «1) наявність обмежень щодо участі, прийняття та ратифікації договорів. Серед обмежень: обов'язкове членство держави у відповідній міжнародній організації - ОЕСР, ЄС, РЕ; участь у розробці відповідного міжнародного договору (Конвенція ОЕСР 1997 року, Кримінальна конвенція 1999 року, Цивільна конвенція 1999 року); запрошення до участі у відповідному договорі (Кримінальна конвенція 1999 року, Цивільна конвенція 1999 року); відсутність у тексті конвенцій положень щодо здійснення заходів із попередження виявів корупції (превентивні заходи); зосередження уваги в рамках регіонального співробітництва на боротьбі з активним та пасивним підкупом, як головним виявом корупції; 2) наявність у договорах положень щодо такої форми участі у вчиненні злочину, як санкціонування, спрямоване на підкуп іноземної посадової особи; наявність положень щодо відповідальності юридичних осіб; 3) наявність дієвого механізму моніторингу виконання положень конвенцій; 4) закріплення положень щодо необхідності відшкодування шкоди, заподіяної внаслідок акту корупції, та дієвих механізмів захисту прав потерпілих; 5) широкі юрисдикційні положення» [10, с. 13].

Слід звернути увагу на зміст Конвениї̈ про боротьбу з корупиією, яка зачіпає посадових осіб Свропейських Співтовариств або посадових осіб держав-членів ЄC, що прийнята Радою $\boldsymbol{C C}$ 26.05.1997, де: а) розтлумачується, хто є «службовцем», «службовцем Співтовариства» та «державним службовцем»; б) розкривається зміст «пасивної» та «активної» корупції; в) передбачається встановлення покарання за корупцію, в тому числі за співучасть у ній та підбурювання до неї; г) пропонуються заходи щодо встановлення кримінальної відповідальності для керівників комерційних підприємств тощо.

В іншому важливому європейському документі - Конвениї̈ про боротьбу з підкупом іноземних посадових осіб у міжнародних комериійних угодах, що була прийнята ОЕСР 21.11.1997: а) розкрито значення поняття «підкупу посадових осіб іноземних держав» та вказано на необхідність його криміналізації поряд із співучастю, підбурюванням, сприянням, пособництвом і санкціонуванням дій, спрямованих на підкуп посадової особи іноземної держави; б) вказано на необхідність визначення відповідальності юридичних осіб за вчинення підкупу; в) передбачено 
положення про встановлення покарання за підкуп, вилучення або конфіскацію предметів підкупу, застосовування фінансових, цивільно-правових або адміністративних санкцій тощо.

Також варто погодитися з думкою Ю.С. Нагачевської, яка підкреслює важливість інших міжнародних документів ЄС у сфері кримінальної відповідальності та запобігання ККП, зокрема Комюніке Європейської комісії щодо комплексної політики ЄС з протидії корупції від 28.05.2003, де визначено основні засади боротьби з цим негативним явищем в Євросоюзі та окреслено принципи вдосконалення протидії корупції в нових країнах-членах, країнах-кандидатах і третіх країнах, а також Рамкового рішення Ради СС «Про боротьбу з корупцією в приватному секторі» № 568 від 22.07.2003, де визначається поняття «активної» та «пасивної» корупції і встановлюються санкції стосовно осіб, зокрема юридичних, за вчинення таких злочинів [11, с. 259-260].

На мою думку, найважливішими (зокрема, тому що ратифіковані Україною та набрали чинності для нашої держави) антикорупційними конвенціями PЄ є ті, що були прийняті в 1999 році та передбачають кримінально-правові й цивільно-правові заходи боротьби з корупцією. Так, Крилінальна конвениія РЕ про боротьбі з корупиією (ETS 173) від 27.01.1999: а) розкриває значення низки термінів Конвенції ( «посадова особа», «суддя», «юридична особа»); б) встановлює широкий перелік корупційних діянь, зокрема щодо дачі та одержання хабара в контексті національних та іноземних державних посадових осіб, приватного сектору, міжнародних організацій, суддів; зловживання впливом; відмивання доходів, отриманих від корупційних злочинів; фінансових злочинів; в) передбачає встановлення кримінальної відповідальності юридичних осіб, санкцій і заходів, забезпечення можливості конфіскації майна.

Питання запобігання ККП, а також деякі процедурні та технічні питання, викладені в нормах цієї Конвенції щодо імунітету, юрисдикції, діяльності спеціалізованих органів, співробітництва із національними органами та між ними, захисту помічників правосуддя та свідків, заходів по сприянню збиранню доказів і конфіскації доходів тощо.

Щодо Додаткового протоколу до Крилінальної конвениї РС про боротьбу з корупиією (ETS 191) від 15.05.2003, то ним вносяться доповнення до зазначеної Конвенції в частині врегулювання національного законодавства сторін, які їі підписали, щодо запобігання та протидії ККП, вчиненим специфічною категорією осіб - арбітрами, а також національними та іноземними присяжними засідателями.

В Цивільній конвенцї РЕ про боротьбу з корупцією (ЕTS 174) від 04.11.1999: а) визначено універсальне поняття «корупції (ст. 2), з чого випливає, що це правопорушення має матеріальний склад; його предметом є хабар чи будь-яка інша неправомірна вигода або можливість її отримання; ззовні можливі різні вияви корупції - прямі чи опосередковані вимагання, пропонування, дача або одержання відповідних предметів; протиправне діяння призводить до порушення «належного виконання будь-якого обов'язку особою, яка отримує відповідний предмет; б) докладно прописані умови та процедури компенсації завданої корупцією шкоди. 
Неабияке значення в плані кримінальної відповідальності за ККП і їх запобігання мають рішення Європейського суду з прав людини (далі - ЄСПЛ), в яких інтерпретуються права і свободи людини, демонструється їх сутність, значення та вирішальна роль для функціонування правової держави. Згідно зі ст. 17 Закону України «Про виконання рішень та застосування практики Європейського суду з прав людини» від 23.02.2006 практика ЄСПЛ становить джерело права при розгляді справ національними судами, тому посилання на норми Європейської конвенції про захист прав людини і основоположних свобод 1950 року та рішення ЄСПЛ - це обов'язок національних судів [12, с. 138].

У плані європейських стандартів запобігання ККП вирішальне значення має також діяльність відповідних міжнародних (в тому числі європейських) організацій у боротьбі з корупцією. Зокрема, в ЄС контроль за реалізацією правових актів у сфері запобігання корупції покладено на спеціальний загальноєвропейський орган EC - GRECO (The Group of States against Corruption - «Група держав проти корупції), який встановлює антикорупційні стандарти щодо діяльності держав і контролює відповідність практики цим стандартам.

Стосовно України слід зазначити, що 01.09.2017 припинила діяти Угода про партнерство і співробітництво, оскільки цього ж дня набрав чинності інший міжнародний нормативно-правовий акт - Угода про асоціацію між Україною та ЄС, Європейським співтовариством з атомної енергії і їхніми державами-членами, де було прямо зазначено про важливі питання боротьби з корупцією (ст.ст. $3,14,22$, ч. 5 ст. 151 , ч. 4 ст. 347 , ч. 1 ст. 459). Реалізація Україною таких питань повинна стати запорукою успіху щодо її вступу (набуття повноправного членства) до ЄС.

Висновки. Підсумовуючи викладені в цій статті положення, варто вказати про таке:

1. Питання європейських стандартів щодо кримінальної відповідальності за ККП та їх запобігання потрібно розглядати крізь призму права ЄС (має наднаціональний характер, йому притаманна вища юридична сила щодо національного права держав-членів, воно репрезентоване численними конвенціями і договорами, впливає на гармонізацію національних законодавств не тільки держав-членів, але й третіх країн) та вироблених на його основі запобіжних антикорупційних заходів.

Кримінально-правова уніфікація в площині боротьби з корупційними діяннями передбачає правову інтеграцію специфічних сфер - насамперед захисту фінансових інтересів СС і матеріального кримінального й процесуального права. Зважаючи на назву та зміст відповідних європейських конвенцій, протоколів, директив та інших документів, питання кримінальної відповідальності за ККП та їх запобігання можуть бути пов'язані з протидією фінансовому шахрайству, підкупу, відмиванню грошей, неправомірному використанню коштів, зловживанню службовим становищем та іншим кримінальним правопорушенням, а також стосуватися забезпечення надійного функціонування діяльності державних і комерційних установ, системи кримінальної юстиції, правосуддя та правоохоронних органів, міжнародних організацій тощо. Водночас факти вчинення ККП - це і ганебні приклади порушення прав і свобод людини, тому в практичному плані важливою буде оцінка корупційних діянь у контексті рішень ЄСПЛ щодо порушення конкретних статей Європейської конвенції про захист прав людини і основоположних свобод 1950 року. 
2. Європейські антикорупційні стандарти передбачають за вчинення ККП настання не тільки певної кримінальної відповідальності (як для фізичних, так і для юридичних осіб), але й застосування цивільно-правових, фінансових, адміністративних санкцій, конфіскацію засобів вчинення ККП і доходів, повернення коштів, забезпечення екстрадиції злочинців тощо. Власне корупція в державах ЄС насамперед розуміється у двох формах - активній і пасивній, при цьому кримінально-караними мають бути такі протиправні форми, як змова, замах, співучасть, підбурювання, сприяння, пособництво щодо вчинення ККП.

Стосовно запобігання ККП актуальними завданнями є вирішення питань імунітету та юрисдикції, забезпечення міжнародного співробітництва та взаємної правової допомоги, діяльності спеціалізованих органів, захисту потерпілих, викривачів і свідків, сприяння збиранню доказів, контроль за реалізацією правових актів у сфері запобігання корупції, моніторинг виконання положень конвенцій тощо.

3. 3 огляду на вдосконалення кримінальної відповідальності за ККП та їх запобігання в Україні використання позитивного європейського досвіду можливе в плані: а) тлумачення низки важливих кримінально-правових і кримінологічних термінів; б) уточнення об’єктивної сторони та суб’єктів складів відповідних ККП, їх переліку та здійснення чіткого відмежування від суміжних протиправних діянь; в) розширення заходів кримінально-правового характеру щодо юридичних осіб (зокрема, запровадження таких видів, як позбавлення права на державні пільги чи допомогу або встановлення судового нагляду, а також збільшення меж штрафних санкцій); г) посилення заходів запобігання ККП за відповідними напрямами.

\section{Jimepamypa}

1. Moorhead T. European Union Law as International Law. European Journal of Legal Studies. 2012. № 5. P. 126-143.

2. Корнієнко В.В. Особливості кримінального права ЄС: теоретико-правовий аспект. Форум права. 2011. № 1. C. $496-500$.

3. Гончарук О.В. Передумови виникнення та перспективи розвитку європейського кримінального права. Актуальні проблеми міжнародних відносин. 2013. Випуск 115 (частина II). С. 66-70.

4. Galushko Dmitriy. To the Issue of Harmonization of the EU Criminal Law. Russian Journal of Political Studies. 2015. Vol. (2). Is. 2. P. 54-60.

5. Жданов Ю.Н., Лаговская Е.С. Европейское уголовное право. Перспективы развития. М. : Международные отношения, 2001. 232 c.

6. Vogel J. The European Integrated Criminal Justice System and its Constitutional Framework. Maastricht Journal of European and Comparative Law. 2005. Vol. 12. № 2. P. 125-147.

7. Трикоз Е.Н. Формирование уголовно-правовой системы Европейского Союза. Журнал российс кого права. 2007. № 10. С. 89-107.

8. Juszczak Adam, Sason Elisa. The Directive on the Fight against Fraud to the Union's Financial Interests by Means of Criminal Law (PFI Directive). Laying Down the Foundation for a Better Protection of the Union’s Financial Interests? The European Criminal Law Associations forum. 2017. № 2. P. 80-87.

9. Corpus Juris 2000 (Draft agreed in Florence). URL: http://dirittopenaleeuropeo.it/corpusjuris-2000/ (дата звернення: 20.04.2020).

10. Гарбазей Д.О. Міжнародно-правові основи боротьби з корупцією : автореф. дис. на здобуття наук. ступеня канд. юрид. наук: 12.00.11. Харків, 2015. 22 с.

11. Нагачевська Ю.С. Міжнародний досвід правових та організаційних заходів у сфері запобігання корупції та його впровадження в Україні. Науковий вісник Львівського державного університету внутрішніх справ. 2016. № 1. С. $256-266$.

12. Паліюк В.П. Загальні питання застосування судами загальної юрисдикції України Конвенції про захист прав людини і основоположних свобод. Часопис иивільного і кримінального судочинства. 2013. № 4. C. $129-142$. 


\section{Анотація}

Боровик $A$. В. Щодо європейських стандартів кримінальної відповідальності за корупційні кримінальні правопорушення та їх запобігання. - Стаття.

У статті з використанням відповідної методології встановлені особливості європейських стандартів щодо кримінальної відповідальності за корупційні кримінальні правопорушення (далі - ККП) та їх запобігання, а також визначені напрями і формат удосконалення національного антикорупційного законодавства та кримінально-правової політики.

Враховуючи стратегічний курс України на набуття повноправного членства в Свропейському Союзі (далі - ЄС), значна увага приділена дослідженню неоднорідності кримінального права ЄС та його складникам, які можуть мати значення для боротьби з корупційними виявами. Встановлено, що кримінально-правова уніфікація в площині боротьби з корупційними діяннями передбачає правову інтеграцію специфічних сфер і насамперед захисту фінансових інтересів ЄС та матеріального кримінального й процесуального права.

Проаналізовано зміст відповідних європейських конвенцій, протоколів, директив та інших документів. Встановлено, що питання кримінальної відповідальності за ККП та їх запобігання можуть бути пов'язані з протидією фінансовому шахрайству, підкупу, відмиванню грошей, неправомірному використанню коштів, зловживанню службовим становищем та іншим кримінальним правопорушенням. Крім цього, факти вчинення ККП є ганебним порушенням прав і свобод людини, тому цьому має бути надана відповідна оцінка з боку Європейського суду з прав людини.

Власне корупція в державах ЄС розуміється у двох формах - активній і пасивній, при цьому кримінально караними мають бути будь-які інші їі протиправні форми. Щодо запобігання ККП актуальними завданнями є вирішення питань імунітету та юрисдикції, забезпечення міжнародного співробітництва та взаємної правової допомоги, діяльності спеціалізованих органів, захисту потерпілих, викривачів і свідків, сприяння збиранню доказів, контроль за реалізацією правових актів у сфері запобігання корупції, моніторинг виконання положень конвенцій тощо. У висновках запропоновані шляхи вдосконалення кримінальної відповідальності за ККП та їх запобігання в Україні на підставі використання позитивного європейського досвіду.

Ключові слова: європейські стандарти, кримінальна відповідальність, запобігання, корупційні кримінальні правопорушення, корупція, міжнародне співробітництво держав, конвенція, протокол, директива.

\section{Summary}

Borovyk A. V. Regarding European standards of criminal liability for corruption offenses and their prevention. - Article.

The article, using the appropriate methodology, sets out the features of European standards on criminal responsibility for corruption criminal offenses (hereinafter referred to as the CCO), as well as defines the directions and format of improvement of national anti-corruption legislation and criminal-legal policy.

Given Ukraine's strategic pursuit of full membership in the European Union (hereinafter referred to as the EU), considerable attention has been paid to investigating the heterogeneity of EU criminal law and its constituents that may be relevant in the fight against corruption. It is established that criminal-legal unification in the area of combating corruption requires legal integration of specific areas and, above all, protection of the EU's financial interests and substantive criminal and procedural law.

The content of the relevant European conventions, protocols, directives and other documents is analyzed. It has been established that criminal responsibility issues for the $\mathrm{CCO}$ and their prevention may be directly related to counteracting financial fraud, bribery, money laundering, misuse of funds, abuse of office and other criminal offenses. In addition, the facts of the CCO's commission are a shameful violation of human rights and freedoms, and should therefore be properly assessed by the European Court of Human Rights.

Corruption in EU member states is understood in two forms - active and passive, and any other illegal forms of criminal prosecution must be punished. With regard to the prevention of the CCO, urgent tasks are the resolution of questions of immunity and jurisdiction, the provision of international cooperation and mutual legal assistance, the activities of specialized bodies, the protection of victims, accusers and witnesses, the facilitation of the collection of evidence, the control over the implementation of legal acts in the field of corruption prevention, monitoring the implementation of the provisions of the conventions etc. The conclusions propose ways to improve of criminal responsibility for the $\mathrm{CCO}$ and prevent them in Ukraine on the basis of positive European experience.

Key words: european standards, criminal responsibility, prevention, corruption offenses, corruption, international cooperation of states, convention, protocol, directive. 